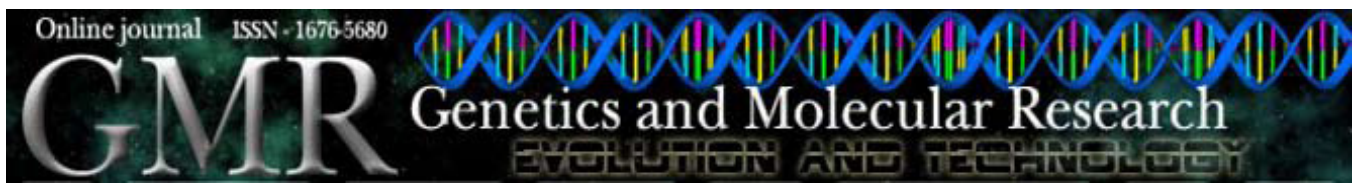

\title{
Genetic relationships between selected Turkish mulberry genotypes (Morus spp) based on RAPD markers
}

\author{
E. Orhan ${ }^{1}$ and S. Ercisli ${ }^{2}$ \\ ${ }^{1}$ Department of Agricultural Biotechnology, Faculty of Agriculture, \\ Ataturk University, Erzurum, Turkey \\ ${ }^{2}$ Department of Horticulture, Faculty of Agriculture, Ataturk University, \\ Erzurum, Turkey \\ Corresponding author: S. Ercisli \\ E-mail: sercisli@hotmail.com
}

Genet. Mol. Res. 9 (4): 2176-2183 (2010)

Received July 15, 2010

Accepted August 3, 2010

Published November 3, 2010

DOI 10.4238/vol9-4gmr958

\begin{abstract}
Mulberry (Morus spp, Moraceae) is an important horticultural crop in Turkey, which is one of the main world producers of mulberry fruit. We evaluated the genetic relationships among 26 mulberry genotypes selected for agronomic characteristics, using RAPD markers. A total of 367 DNA markers were generated with 34 random primers. The highest genetic similarity $(0.80)$ was observed between Oltu58 (M. nigra) and Olur90 ( $M$. nigra) genotypes. The genotypes Oltu3 (M. alba) and Oltu18 (M. rubra) were the most distant (0.36). We found that the RAPD technique is a useful tool to discriminate mulberry genotypes at both the intra- and interspecific level. This type of information will aid in accurate identification of useful genotypes for breeding programs.
\end{abstract}

Key words: Morus alba; Morus nigra; Morus rubra; RAPD; Genetic relationship 


\section{INTRODUCTION}

Mulberries are highly adaptable species in different soil and climatic conditions. Therefore, they can be found in a wide area of tropical, subtropical, and temperate zones in Asia, Europe, North America, South America, and Africa (Kafkas et al., 2008). The trees have been used for both fruit production and also for sericulture especially in east, central, and south Asia. Although around 30 mulberry species have been found in the world, a few of them, for example, Morus alba, M. nigra, M. rubra, M. indica, and M. laevigata, are used for direct fruit consumption (Awasthi et al., 2004). Most of these species, except M. alba, has a distinct flavor with juicy and acidic characteristics making them attractive for use in the processing industry for products such as fruit juice, ice cream, jelly, and jam. However, $M$. $a l b a$, with the highest sugar content, is used for making traditional foods such as "mulberry pekmez", "mulberry pestil", and "mulberry kome" in Turkey (Ercisli, 2004; Ercisli and Orhan, 2007).

Turkey has very old mulberry cultivation, and mulberry plants can be found in most regions of Turkey, with a high morphological diversity, and it is believed that mulberry cultivation in Turkey was started 400-500 years ago (Ercisli and Orhan, 2007). Among the mulberry species found in Turkey, $M$. alba is the most dominant ( $95 \%$ of total mulberry production in Turkey), because its fruits are very high in soluble solid contents, and thus they are the most suitable for processing to make traditional local mulberry products in Turkey. More recently, M. nigra has grown in importance because it is believed to be a more healthy fruit among mulberry species due to its high bioactive content (Ercisli and Orhan, 2008).

In Turkey, particularly Eastern Anatolia, mulberries have been the main source of processed fruits for human consumption because of the cold temperate climate characteristics of the region. The people in this region consume mulberry products during the long winter season. On the other hand, the mulberry genotypes are very diverse, where they are obtained from seeds from the past in the region. This process may lead to a great number of landraces adapted to different conditions and to different uses throughout the region. In this region, little information is available about genetic resources in mulberries.

Previously, mulberry genotypes have been described based on morphological characters, but it is well known that such characters are strongly influenced by environment factors. More recently, molecular markers have gained more importance, and they are commonly used to characterize mulberry genotypes throughout mulberry-growing countries (Vijayan and Chatterjee, 2003; Vijayan, 2004; Vijayan et al., 2004a,b,c; Zhao et al., 2006, 2007; Kafkas et al., 2008; Kar et al., 2008).

The aim of this study was to use random amplified polymorphic DNA (RAPD) fingerprinting to detect and characterize polymorphisms among mulberry genotypes sampled from diverse environments of the Erzurum region in Turkey, and in addition, to investigate the genetic relationships among the genotypes sampled.

\section{MATERIAL AND METHODS}

Leaf samples from 26 selected mulberry genotypes (22 M. alba, 3 M. nigra and 1 M. rubra) found in the towns in Oltu and Olur in Erzurum provinces located in the Eastern 
Anatolia, Turkey, were collected and immediately stored at $-80^{\circ} \mathrm{C}$ for DNA extraction.

Genomic DNA was extracted from powdered plant materials using a modified method described by Lin et al. (2001). Approximately 10-15 mg tissue samples from each plant species were snap frozen in liquid nitrogen in 2-mL Eppendorf tubes. A volume of $1000 \mu \mathrm{L}$ DNA extraction buffer [100 mM Tris-HCl, $\mathrm{pH} 8.0 ; 50$ mM EDTA, pH 8.0; $500 \mathrm{mM} \mathrm{NaCl}$; $2 \%$ SDS (w/v); 2\% 2-mercaptoethanol (v/v); 1\% PVP (w/v)] was added and the contents mixed well. The mixture was incubated at $65^{\circ} \mathrm{C}$ in a water bath for 40 min with intermittent shaking at 5-min intervals. The mixture was centrifuged at $12,000 \mathrm{~g}$ for $15 \mathrm{~min}$ at $4^{\circ} \mathrm{C}$, the supernatant was transferred to a new $1.5-\mathrm{mL}$ tube, mixed with an equal volume of phenol:chloroform:isoamyl alcohol (25:24:1), and centrifuged. The supernatant was collected and mixed with $1 / 10$ volume $10 \% \mathrm{CTAB}-0.7 \mathrm{M} \mathrm{NaCl}$ in a new tube. After centrifugation, the supernatant was collected and an equal volume of chloroform:isoamyl alcohol (24:1) was added with gentle mixed. The DNA was precipitated by the addition of 0.6 volume of freezer-cold isopropanol and left at $-20^{\circ} \mathrm{C}$ for $10 \mathrm{~min}$. The DNA was pelleted by centrifugation $(12,000 \mathrm{~g}, 10 \mathrm{~min})$, and the isopropanol was poured off; the DNA was allowed to air-dry before being dissolved in $100 \mu \mathrm{L}$ TE buffer.

Samples were screened for RAPD variation using standard 10-base primers supplied by Operon. Thirty microliters of reaction cocktail was prepared as follows: $3.0 \mu \mathrm{L} 10 \mathrm{X}$ buffer, $1.2 \mu \mathrm{L}$ dNTPs $(10 \mathrm{mM}), 1.2 \mu \mathrm{L}$ magnesium chloride $(25 \mathrm{mM}), 2.0 \mu \mathrm{L}$ primer $(5 \mu \mathrm{M})$, $0.4 \mu \mathrm{L}$ Taq polymerase $(5 \mathrm{U}), 19.2 \mu \mathrm{L}$ water, $3.0 \mu \mathrm{L}$ sample DNA $(100 \mathrm{ng} / \mu \mathrm{L})$. A total of 34 RAPD primers were tested in this study (Table 1).

The thermocycler (Eppendorf Company) was programmed for $2 \mathrm{~min}$ at $95^{\circ} \mathrm{C} ; 2 \mathrm{cy}-$ cles of $30 \mathrm{~s}$ at $95^{\circ} \mathrm{C}, 1 \mathrm{~min}$ at $37^{\circ} \mathrm{C}, 2 \mathrm{~min}$ at $72^{\circ} \mathrm{C} ; 2$ cycles of $30 \mathrm{~s}$ at $95^{\circ} \mathrm{C}, 1 \mathrm{~min}$ at $35^{\circ} \mathrm{C}$, $2 \mathrm{~min}$ at $72^{\circ} \mathrm{C}$; 41 cycles of $30 \mathrm{~s}$ at $94^{\circ} \mathrm{C}, 1 \mathrm{~min}$ at $35^{\circ} \mathrm{C}, 2 \mathrm{~min}$ at $72^{\circ} \mathrm{C}$; followed by a final 5 -min extension at $72^{\circ} \mathrm{C}$ and then cooling down to $4^{\circ} \mathrm{C}$.

The polymerase chain reaction $(\mathrm{PCR})$ products $(27 \mu \mathrm{L})$ were mixed with $6 \mathrm{X}$ gel loading buffer $(3 \mu \mathrm{L})$, loaded onto an agarose $(1.5 \%, \mathrm{w} / \mathrm{v})$ gel in $0.5 \mathrm{X}$ TBE (Tris-borateEDTA) buffer, and electrophoresed at $70 \mathrm{~V}$ for $150 \mathrm{~min}$. The gel was stained in ethidium bromide solution ( $2 \mu \mathrm{L} \mathrm{Etbr/100} \mathrm{mL} \mathrm{in} \mathrm{1X} \mathrm{TBE} \mathrm{buffer)} \mathrm{for} 40 \mathrm{~min}$ and visualized under UV using a Bio Doc Image Analysis System with Uvisoft analysis package (Cambrige, UK).

RAPD data were recorded as for the presence (1) of a band and for its absence (0) and were transferred to a binary matrix. Only reproducible bands were scored. For distance matrix analysis of the RAPD data, the WINDIST software was used. The dendogram was constructed on the basis of this matrix by UPGMA (unweighted pair group method using arithmetic average), using the PHYLIP 3.5c software program (Felsenstein, 1993).

\section{RESULTS}

We used a total of 34 decamer oligonucleotide primers to determine genetic relationships between 26 selected promising mulberry genotypes (22 M. alba, $3 \mathrm{M}$. nigra and $1 \mathrm{M}$. rubra), and the results of RAPD analysis are summarized in Tables 1 and 2 and Figures 1 and 2.

As indicated in Table 1, the 34 RAPD primers generated a total of 367 RAPD bands and among them 330 RAPD bands were found to be polymorphic, resulting in $89.9 \%$ polymorphism. The number of RAPD products varied from 7 to 14 (Table 1). The primers OPW1, 
OPBB15 and OPBD17 gave the highest number of RAPD products (14), while OPY6 and OPBB04 gave the lowest number of RAPD products (7). The level of polymorphism varied from 55.6\% (OPW8) to 100.0\% (OPA12, OPW6, OPH19, OPB8, OPW11, OPW18, OPBA06, OPBA08, OPBB04, and OPBB07). An average of 9.7 polymorphic RAPD bands was recorded. Figure 1 displays the RAPD pattern generated by OPA4 from genomic DNA of 26 mulberry genotypes (Morus spp).

\begin{tabular}{|c|c|c|c|c|c|}
\hline Primer code & $\begin{array}{l}\text { Sequence of primer } \\
5^{\prime} \rightarrow 3^{\prime}\end{array}$ & $\begin{array}{l}\text { Size (bp) } \\
\text { min-max }\end{array}$ & Total number of bands & $\begin{array}{l}\text { Total number of RAPD } \\
\text { products per primer }\end{array}$ & $\begin{array}{c}\text { Polymorphism } \\
\text { level (\%) }\end{array}$ \\
\hline OPW1 & CTCAGTGTCC & $250-2500$ & 14 & 13 & $92.9 \%$ \\
\hline OPW4 & CAGAAGCGGA & $350-2000$ & 11 & 9 & $81.8 \%$ \\
\hline OPW5 & GGCGGATAAG & $290-2000$ & 12 & 11 & $91.7 \%$ \\
\hline OPW6 & AGGCCCGATG & $350-2000$ & 13 & 13 & $100.0 \%$ \\
\hline OPW7 & CTGGACGTCA & $350-1500$ & 10 & 9 & $90.0 \%$ \\
\hline OPW8 & GACTGCCTCT & $300-1500$ & 9 & 5 & $55.6 \%$ \\
\hline OPW11 & CTGATGCGTG & $400-1600$ & 11 & 11 & $100.0 \%$ \\
\hline OPW17 & GTCCTGGGTT & $600-1500$ & 10 & 9 & $90.0 \%$ \\
\hline OPW18 & TTCAGGGCAC & $500-2500$ & 10 & 10 & $100.0 \%$ \\
\hline OPA4 & AATCGGGCTG & $400-4000$ & 11 & 9 & $81.8 \%$ \\
\hline OPA12 & TCGGCGATAG & $450-2000$ & 10 & 10 & $100.0 \%$ \\
\hline OPA13 & CAGCACCCAC & $450-2800$ & 11 & 10 & $90.9 \%$ \\
\hline OPH16 & TCTCAGCTGG & $400-2000$ & 10 & 8 & $80.0 \%$ \\
\hline OPH19 & CTGACCAGCC & $400-3000$ & 12 & 12 & $100.0 \%$ \\
\hline OPY1 & GTGGCATCTC & $350-1500$ & 10 & 9 & $90.0 \%$ \\
\hline OPY6 & AAGGCTCACC & $500-2500$ & 7 & 6 & $85.7 \%$ \\
\hline OPY8 & AGGCAGAGCA & $350-1150$ & 9 & 8 & $88.9 \%$ \\
\hline OPY11 & AGACGATGGG & $150-2000$ & 13 & 11 & $84.6 \%$ \\
\hline OPY13 & GGGTCTCGGT & $300-1250$ & 8 & 7 & $87.5 \%$ \\
\hline OPY 15 & AGTCGCCCTT & $480-3000$ & 8 & 6 & $75.0 \%$ \\
\hline OPY16 & GGGCCAATGT & $300-1400$ & 10 & 9 & $90.0 \%$ \\
\hline OPB8 & GTCCACACGG & $280-2000$ & 12 & 12 & $100.0 \%$ \\
\hline OPB10 & CTGCTGGGAC & $400-1450$ & 10 & 8 & $80.0 \%$ \\
\hline OPBA03 & GTGCGAGAAC & $230-1200$ & 11 & 9 & $81.8 \%$ \\
\hline OPBA06 & GGACGACCGT & $250-1700$ & 12 & 12 & $100.0 \%$ \\
\hline OPBA08 & CCACAGCCGA & $250-1000$ & 11 & 11 & $100.0 \%$ \\
\hline OPBB04 & ACCAGGTCAC & $350-1000$ & 7 & 7 & $100.0 \%$ \\
\hline OPBB07 & GAAGGCTGGG & $360-2400$ & 12 & 12 & $100.0 \%$ \\
\hline OPBB11 & TGCGGGTTCC & $240-1050$ & 11 & 10 & $90.9 \%$ \\
\hline OPBB13 & CTTCGGTGTG & $200-1000$ & 12 & 10 & $83.3 \%$ \\
\hline OPBB15 & AAGTGCCCTG & $350-1500$ & 14 & 13 & $92.6 \%$ \\
\hline OPBC08 & GGTCTTCCCT & $400-1200$ & 10 & 8 & $80.0 \%$ \\
\hline OPBD07 & GAGCTGGTCC & $380-1400$ & 12 & 11 & $91.7 \%$ \\
\hline OPBD17 & GTTCGCTCCC & $100-1300$ & 14 & 12 & $85.7 \%$ \\
\hline Total & & & 367 & 330 & \\
\hline Avarage & & & & 9.7 & $89.9 \%$ \\
\hline
\end{tabular}




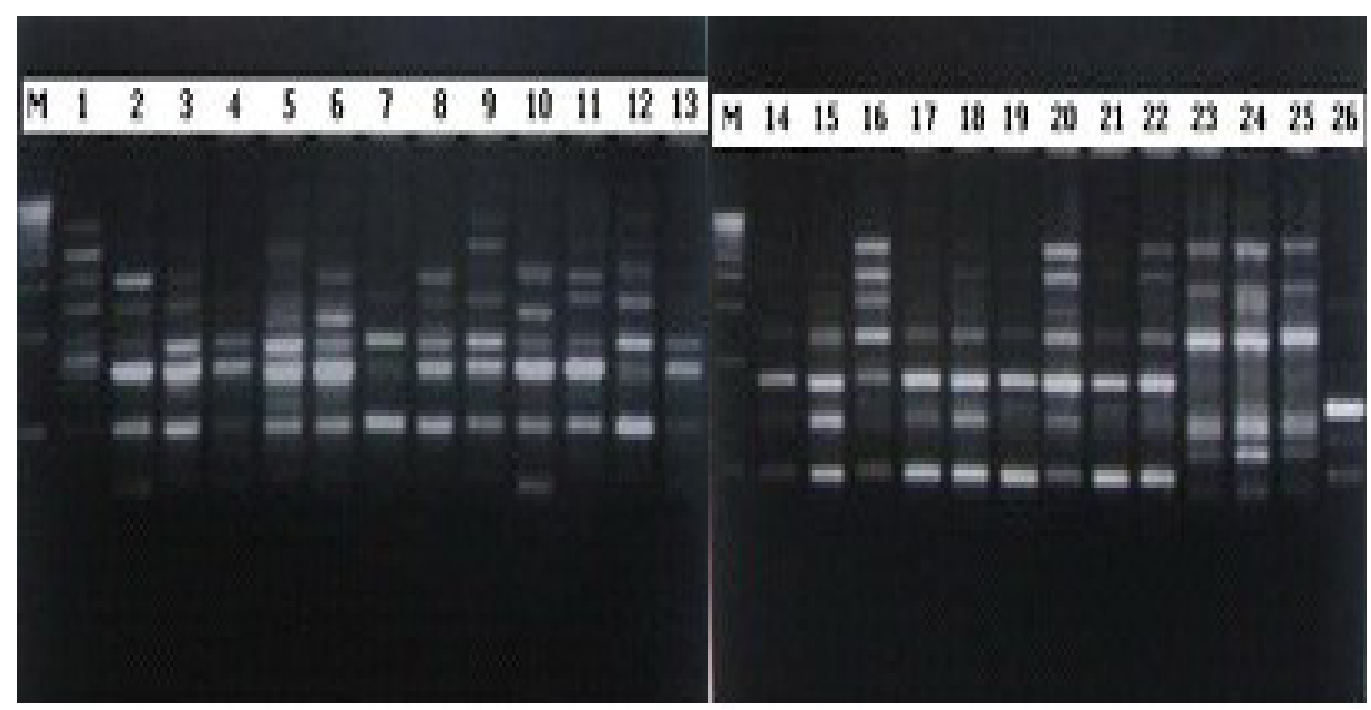

Figure 1. RAPD bands obtained by amplification with primer OPA4 $(\mathrm{M}=$ marker, lane $1=$ Oltu34, lane $2=$ Oltu3, lane $3=$ Oltu32, lane $4=$ Olur1, lane $5=$ Olur87, lane $6=$ Olur88, lane $7=$ Olur91, lane $8=$ Olur92, lane $9=$ Olur23, lane 10 $=$ Olur45, lane $11=$ Olur7, lane $12=$ Olur49, lane $13=$ Olur52, lane $14=$ Olur55, lane $15=$ Olur57, lane $16=$ Olur53, lane $17=$ Oltu8, lane $18=$ Oltu12, lane $19=$ Oltu13, lane $20=$ Oltu14, lane $21=$ Oltu20, lane $22=$ Oltu21, lane $23=$ Oltu58, lane $24=$ Olur90, lane $25=$ Olur8, lane $26=$ Oltu18).

As shown in Table 2, the highest genetic similarity (0.80) was between Oltu58 ( $M$. nigra) and Olur90 (M. nigra), whereas the lowest genetic similarity $(0.36)$ was between Oltu3 (M. alba) and Oltu18 (M. rubra).

The dendogram (Figure 2) shows genetic relationships among the mulberry genotypes. In this dendogram, 26 mulberry genotypes grouped into four major clusters, indicating greater genetic diversity among them. The first group includes Oltu58, Olur8 and Olur90, genotypes that all belong to M. nigra. The second group includes Oltu34, Oltu32, Olur1, Olur87, Olur88, Olur91, Olur92, Olur23, Olur45, Olur7, Olur49, Olur52, Olur55, Olur57, Olur53, Oltu8, Oltu12, Oltu13, Oltu14, Oltu20, and Oltu21 (all of M. alba). In the dendogram, the third group consists of only Oltu3 (M. alba) and the last group includes only Oltu18 ( $M$. rubra), which is very distant from the other genotypes.

\section{DISCUSSION}

As indicated in the Results section, genetic similarity varied from 0.36 to 0.80 . These results indicate that the genotypes Oltu58 (M. nigra) and Olur90 (M. nigra) are genetically closer than other mulberry genotypes. A previous study showed that among mulberry species, the highest genetic variability was among $M$. alba and that in contrast the lowest genetic variability was among M. nigra genotypes (Kafkas et al., 2008). Our study also supports the idea that $M$. alba genotypes has higher variability.

According to the results, there is a high genetic diversity between and within mulberry species. These results also support the idea that mulberry genotypes used in this region 

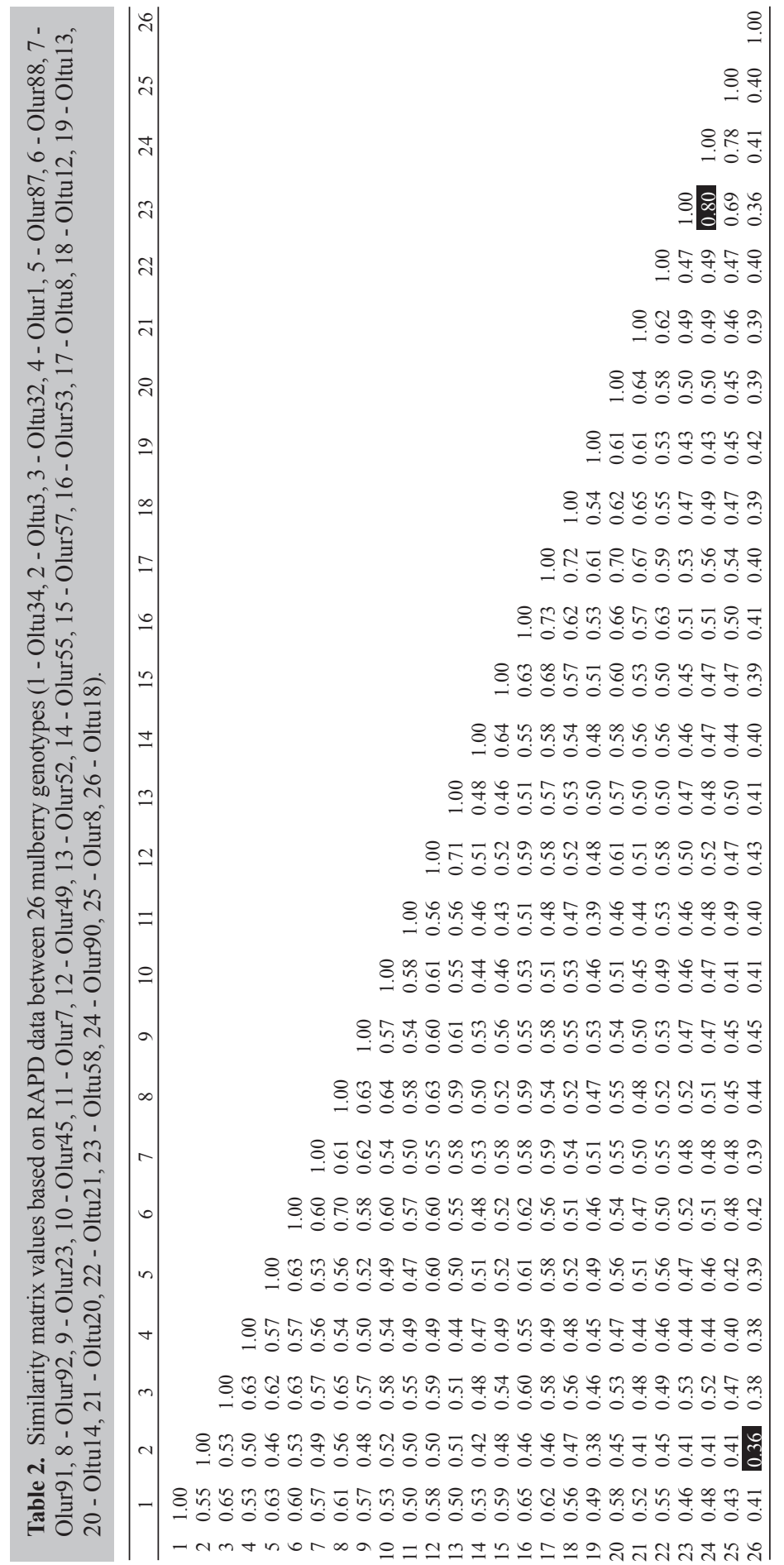


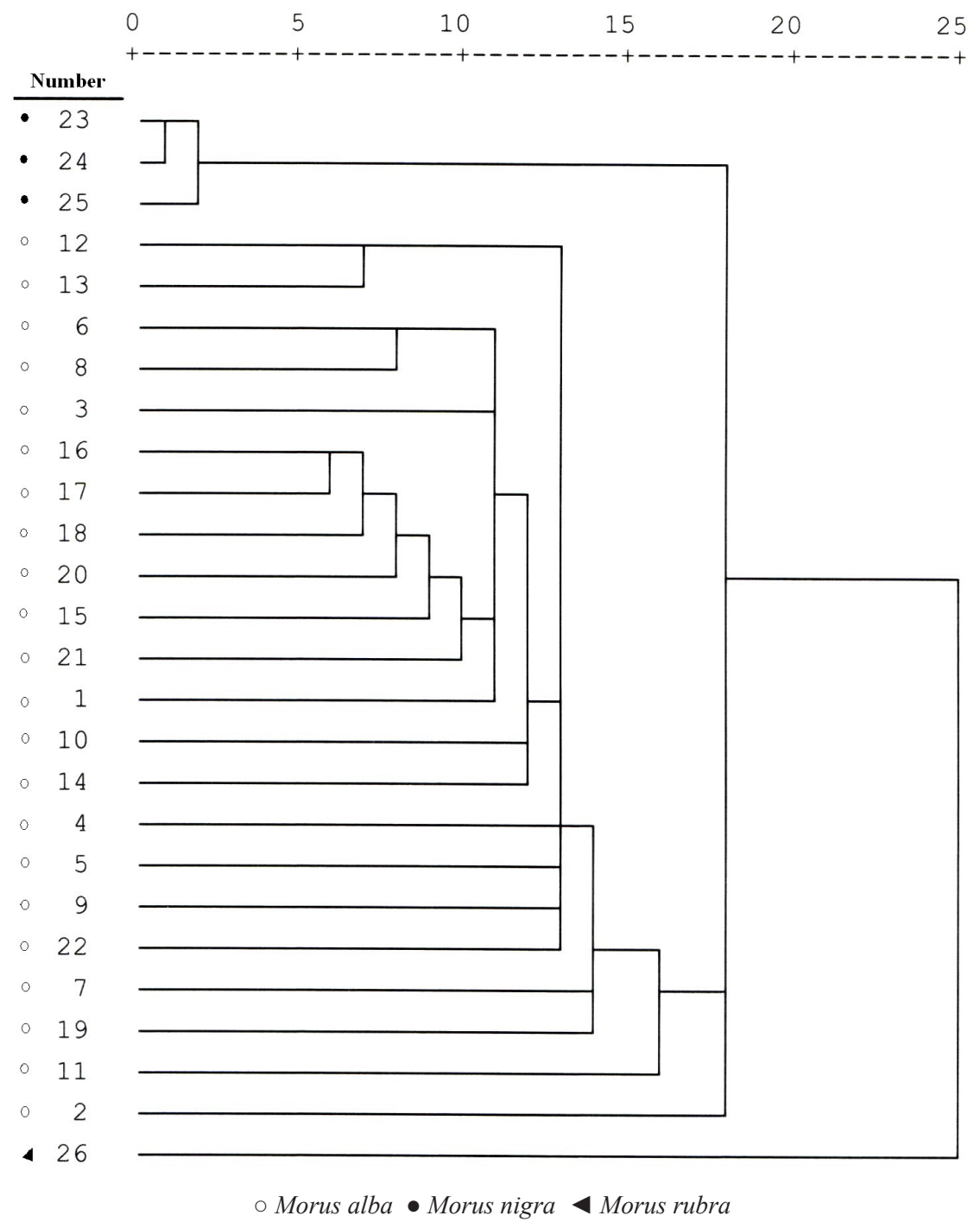

Figure 2. UPGMA dendogram showing the relationships of mulberries (1 - Oltu34, 2 - Oltu3, 3 - Oltu32, 4 - Olur1, 5 - Olur87, 6 - Olur88, 7 - Olur91, 8 - Olur92, 9 - Olur23, 10 - Olur45, 11 - Olur7, 12 - Olur49, 13 - Olur52, 14 Olur55, 15 - Olur57, 16 - Olur53, 17 - Oltu8, 18 - Oltu12, 19 - Oltu13, 20 - Oltu14, 21 - Oltu20, 22 - Oltu21, 23 - Oltu58, 24 - Olur90, 25 - Olur8, 26 - Oltu18.

previously selected by humans among seed-propagated materials and by mutations may have occurred during the long cultivation period and may also share this high genetic diversity. On the other hand, we can also conclude that RAPD analysis can be useful and the least expensive molecular technique for grouping and characterizing mulberry genotypes (Morus spp). Our study shows that there is a very high polymorphism rate in the mulberry germplasm. The high level of genetic variability detected within the mulberry germplasm 
collected in the Erzurum region could be attributed to either the distant geographical or genetic origin. On the other hand, an average similarity ratio of 0.594 was recorded for the mulberry genotypes, suggesting that the genome may differ in genotypes. These results also indicate the potential use of these genotypes, particularly the more distant ones, for future breeding programs.

\section{ACKNOWLEDGMENTS}

Research supported by Atatürk University (Project \#BAP-2004/81).

\section{REFERENCES}

Awasthi AK, Nagaraja GM, Naik GV, Kanginakudru S, et al. (2004). Genetic diversity and relationships in mulberry (genus Morus) as revealed by RAPD and ISSR marker assays. BMC Genet. 5: 1.

Ercisli S (2004). A short review of the fruit germplasm resources of Turkey. Genet. Resour. Crop Evol. 51: 419-435.

Ercisli S and Orhan E (2007). Chemical composition of white (Morus alba), red (Morus rubra) and black (Morus nigra) mulberry fruits. Food Chem. 103: 1380-1384.

Ercisli S and Orhan E (2008). Some physico-chemical characteristics of black mulberry (Morus nigra L.) genotypes from Northeast Anatolia region of Turkey. Sci. Hort. 116: 41-46.

Felsenstein J (1993). PHYLIP (Phylogeny Inference Package) User Manual. University of Washington, Seattle.

Kafkas S, Özen M, Doğan, Özcan B, et al. (2008). Molecular characterization of mulberry accessions in Turkey by AFLP markers. J. Am. Soc. Hort. Sci. 133: 593-597.

Kar PK, Srivastava PP, Awasthi AK and Awasthi SR (2008). Genetic variability and association of ISSR markers with some biochemical traits in mulberry (Morus spp.) genetic resources available in India. Tree Genet. Genomes 4: 75-83.

Lin RC, Ding ZS, Li LB and Kuang TY (2001). A rapid and efficient DNA minipreparation suitable for screening transgenic plants. Plant Mol. Biol. Rep. 19: 379a-379e.

Vijayan K (2004). Genetic relationships of Japanese and Indian mulberry (Morus spp.) genotypes revealed by DNA fingerprinting. Plant Syst. Evol. 243: 221-232.

Vijayan K and Chatterjee SN (2003). SSR profiling of Indian cultivars of mulberry (Morus spp.) and its relevance to breeding programs. Euphytica 131: 53-63.

Vijayan K, Srivastava PP and Awasthi AK (2004a). Analysis of phylogenetic relationship among five mulberry (Morus) species using molecular markers. Genome 47: 439-448.

Vijayan K, Awasthi AK, Srivastava PP and Saratchandra B (2004b). Genetic analysis of Indian mulberry varieties through molecular markers. Hereditas 141: 8-14.

Vijayan K, Kar PK, Tikader A, Srivastava PP, et al. (2004c). Molecular evaluation of genetic variability in wild populations of mulberry (Morus serrata Roxb.). Plant Breed. 123: 568-572.

Zhao W, Zhou Z, Miao X, Wang S, et al. (2006). Genetic relatedness among cultivated and wild mulberry (Moraceae: Morus) as revealed by inter-simple sequence repeat analysis in China. Can. J. Plant Sci. 86: 251-257.

Zhao W, Wang Y, Chen T, Jia G, et al. (2007). Genetic structure of mulberry from different ecotypes revealed by ISSRs in China: an implications for conservation of local mulberry varieties. Sci. Hort. 155: 47-55. 